\title{
Effects of $\mathrm{Al}_{2} \mathrm{O}_{3}$ and $\mathrm{TiO}_{2}$ on the coagulation process by $\mathrm{Al}_{2}\left(\mathrm{SO}_{4}\right)_{3}$ (AS) and poly-aluminum chloride ( $\mathrm{PACl}$ ) in kaolin suspension
}

\author{
Hui Xu, Feng Xiao*, Dongsheng Wang

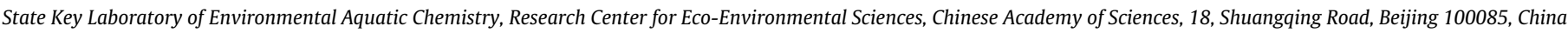

\section{A R T I C L E I N F O}

Article history:

Received 24 September 2013

Received in revised form 16 December 2013

Accepted 1 January 2014

Available online 15 January 2014

\section{Keywords:}

Coagulation

Nanoparticles

Natural organic matter

Characteristics of floc

\begin{abstract}
A B S T R A C T
More and more nanoparticles may be found in the aquatic environment. Effects of different nanoparticles (nano- $\mathrm{Al}_{2} \mathrm{O}_{3}$ and nano- $\mathrm{TiO}_{2}$ ) on the coagulation process in kaolin suspension (with or without humic acid) were investigated. The results indicated that when the $\mathrm{pH}$ was 7.0 in kaolin suspension, the strength factor with the presence of $\mathrm{TiO}_{2}$ increased from $28.79 \%$ to $48.69 \%$ and when the concentration of $\mathrm{TiO}_{2}$ was larger than $1.6 \mathrm{mg} / \mathrm{L}$, the strength factor decreased to $23.39 \%$. The removal efficiencies for $\mathrm{Al}_{2} \mathrm{O}_{3}$ were $58.27 \%, 62.73 \%$ and $47.3 \%$ under $\mathrm{pH} 6.0,7.0$ or 8.5 . The removal efficiencies for $\mathrm{TiO}_{2}$ were $38.12 \%$, $52.25 \%$ and $27.19 \%$. When the concentration of DOC was $2.5 \mathrm{mg} / \mathrm{L}$ under $\mathrm{pH} 7.0$, the recovery factor increased from $54.55 \%$ to $62.65 \%$ with increasing concentration of $\mathrm{Al}_{2} \mathrm{O}_{3}$ from $0.0 \mathrm{mg} / \mathrm{L}$ to $2.0 \mathrm{mg} / \mathrm{L}$, and it increased from $54.55 \%$ to $67.74 \%$ for $\mathrm{TiO}_{2}$. $\mathrm{PACl}$ produced larger flocs, and this may be caused by higher charge neutralization ability and the electrostatic patch effect. The removal efficiency for $\mathrm{TiO}_{2}$ decreased from $52.25 \%$ to $22.13 \%$ with increasing concentration of DOC from $0 \mathrm{mg} / \mathrm{L}$ to $7.5 \mathrm{mg} / \mathrm{L}$. The removal efficiency for $\mathrm{Al}_{2} \mathrm{O}_{3}$ decreased from $62.73 \%$ to $32.12 \%$.
\end{abstract}

(c) 2014 Elsevier B.V. All rights reserved.

\section{Introduction}

With the development of nanotechnologies, more and more nanoparticles may be found in the aquatic environment [1]. Commercial $\mathrm{TiO}_{2}$ powders have been widely used as a white pigment in the paint, and paper industries for their unique performance, such as outstanding refractive index, insolubility in alkaline and acidic solutions. $\mathrm{TiO}_{2}$ is expected to continue to grow in the next decade, and may eventually substitute the bulk form [2]. $\mathrm{Al}_{2} \mathrm{O}_{3}$ is one of the most cost effective, strong and stiff materials in the family of engineering ceramics which has high corrosion resistance and good thermal properties. Considering the wide range of industrial applications of $\mathrm{Al}_{2} \mathrm{O}_{3}$, their release into the environment and water would be inevitable [3]. Titanium dioxide could induce a significant reduction in mitochondrial dehydrogenase activity in human lymphocyte cells [4]. The negative size effect of NPs was clearly demonstrated by researchers who investigated various sizes of $\mathrm{NP}_{S}[5,6]$. Dissolved and surface-bound humic acid may affect the toxicity of $\mathrm{TiO}_{2}$ nanoparticles [7].

Coagulation still is a widely applied process for removing particles and organic matter in Drinking Water Treatment Plant and it has played an important role in water treatment for decades $[8,9]$. Chuang et al. have applied poly-aluminum chloride ( $\mathrm{PACl}$ ) as the coagulant and cationic polyacrylamide as the flocculant to remove nanoparticles in the CMP wastewater [10]. But the effects

\footnotetext{
* Corresponding authors. Tel./fax: +86 1062849138 .

E-mail address: fengxiao@rcees.ac.cn (F. Xiao).
}

of nanoparticles on coagulation process were not investigated. In this study, we added nano- $\mathrm{Al}_{2} \mathrm{O}_{3}$ and nano- $\mathrm{TiO}_{2}$ particles to kaolin solution to investigate the effects of nanoparticles on the coagulation process. The concentration of HA was also an important factor in the coagulation process [11-14]. The Al-based coagulants $\left(\mathrm{Al}_{2}\left(\mathrm{SO}_{4}\right)_{3}(\mathrm{AS})\right.$ and $\left.\mathrm{PACl}\right)$ were used as coagulants, and the floc size, fractal dimension and zeta potential were measured to understand the mechanism [15]. Generally, coagulation of colloids and particles by hydrolyzing coagulants is explained in terms of three distinct mechanisms: charge neutralization, bridging and sweep flocculation [16]. Yan et al. [17] demonstrated that the flocs formed by charge neutralization through a suppression of the electric double layer (EDL) had weak physical particle-particle bonds such as vander Waals force. Researchers also have found that flocs become more compact under exposure to increasing shear as they break at their weak points and rearrange into more stable and tight structure [18].

The breakage and re-growth of flocs has been studied by many researchers $[14,19,20]$. Flocs breakage and recovery should also be taken into consideration for overall process and have been the subject of in-depth research in recent years $[21,22]$. Yukselen and Gregory found that only limited re-growth of flocs occured for alum and $\mathrm{PACl}$, which indicated a significant irreversibility of flocs [23]. Some other researchers considered that the flocs formed by charge neutralization could be fully reformed. Some researchers have focused on the differences between breakage and re-growth nature of $\mathrm{HA}$ flocs coagulated with $\mathrm{PACl}$. 
The major objective of this study is to investigate the effects of nanoparticles on the coagulation process under different coagulation conditions, including various solution $\mathrm{pH}$ values and the concentration of HA. The effects of ionic strength on coagulation process were also investigated. In order to better understand the mechanisms, two different nanoparticles were used. AS was used as coagulant, and $\mathrm{PACl}$ was used to compare with $\mathrm{AS}$.

\section{Materials and methods}

\subsection{Materials}

The commercial humic acid (HA) was purchased from Sigma. The stock solution of HA was prepared by dissolving $1.0 \mathrm{~g} \mathrm{HA}$ in $0.01 \mathrm{~mol} / \mathrm{L} \mathrm{NaOH}$ solution under continuous stirring for $24 \mathrm{~h}$. After that, the solution was filtered through $0.45 \mu \mathrm{m}$ membrane and stored in refrigerator for later use [24]. The final DOC of the prepared HA stock solution was $250 \mathrm{mg} / \mathrm{L}$ based on total organic carbon analysis.

Kaolin clay was used as the model suspension. $10 \mathrm{~g}$ kaolin was dispersed in $2 \mathrm{~L}$ of de-ionized water in a high-speed blender. In order to obtain full dispersion it was necessary to raise the $\mathrm{pH}$ of the suspension to about 7.5, which was achieved by adding $0.1 \mathrm{~mol} / \mathrm{L}$ $\mathrm{NaOH}$ solution. After blending for $1 \mathrm{~h}$, the suspension was allowed to stand for $3 \mathrm{~h}$. Then the upper $1 \mathrm{~L}$ suspension was decanted. The stock suspension was diluted to give the suspensions in the coagulation process.

$\mathrm{TiO}_{2}$ and $\mathrm{Al}_{2} \mathrm{O}_{3}$ particles were purchased from Beijing DK nanotechnology Co., Ltd. The nanoparticles were characterized by TEM. The images in Fig. 1 showed that the pure $\mathrm{TiO}_{2}$ with a diameter of $40 \mathrm{~nm}$, and the $\mathrm{Al}_{2} \mathrm{O}_{3}$ had a smaller diameter (30-40 nm). The two particles have different charges under the same $\mathrm{pH}$ values (Fig. S1). This may cause different effects on the characteristics of flocs. The iso-electric point (IEP) of $\mathrm{Al}_{2} \mathrm{O}_{3}$ was at $\mathrm{pH} 8.5$, so the charges on the $\mathrm{Al}_{2} \mathrm{O}_{3}$ particles were positive in all experiment conditions. The isoelectric point of $\mathrm{TiO}_{2}$ was at $\mathrm{pH} 4.8$, and the charges on the $\mathrm{TiO}_{2}$ particles were negative in all experiment conditions.

\subsection{Water samples}

Water samples used in this study were prepared by dissolving $\mathrm{HA}$ and kaolin stock solution, and added different concentration of $\mathrm{TiO}_{2}$ and $\mathrm{Al}_{2} \mathrm{O}_{3}$ particles. All water samples were stirred for $12 \mathrm{~h}$ before the addition of coagulant. The water samples were added $5.0 \mathrm{mmol} / \mathrm{L} \mathrm{NaNO}_{3}$ and $4.0 \mathrm{mmol} / \mathrm{L} \mathrm{NaHCO}_{3}$ to provide ionic strength and alkalinity. Characteristics of water samples in kaolin suspension under pH 7.0 are summarized in Table 1.
The results in Table 1 indicated that the nanoparticles had significant effects on the kaolin particle size. Because the iso-electric point for $\mathrm{Al}_{2} \mathrm{O}_{3}$ is 8.5 , it has positive charges under $\mathrm{pH}$ 7.0. The positive particles can be adsorbed on the negative surface of kaolin particles, and bridge the particles together. This effect is not significant for the negative charged $\mathrm{TiO}_{2}$. Table 1 also showed that the turbidity increased more rapidly with increasing concentration of $\mathrm{TiO}_{2}$ than $\mathrm{Al}_{2} \mathrm{O}_{3}$. When the concentration of $\mathrm{Al}_{2} \mathrm{O}_{3}$ was $1.2 \mathrm{mg} / \mathrm{L}$, the zeta potential became positive $(2.3 \mathrm{mv})$. The $\mathrm{TiO}_{2}$ particles decreased the zeta potential from $-30.1 \mathrm{mv}$ to $-49.5 \mathrm{mv}$ with increasing the concentration.

In order to investigate the effects of HA on the coagulation process, we added different amounts of HA solution to the kaolin suspension, and the zeta potentials under different concentration of DOC $(\mathrm{mg} / \mathrm{L})$ were summarized in Fig. S2.

The addition of HA could significantly decrease the zeta potential from $-30.1 \mathrm{mv}$ to $-47.8 \mathrm{mv}$ with increasing concentration of DOC from $0 \mathrm{mg} / \mathrm{L}$ to $2.5 \mathrm{mg} / \mathrm{L}$ (Fig. S2). But when the concentration of DOC was larger than $2.5 \mathrm{mg} / \mathrm{L}$, the concentration of DOC had no significant effects on the zeta potential. Researchers had showed that the presence of small concentration of DOC resulted in charge reversal at low $\mathrm{pH}$ and an increase negative net total particle charge at $\mathrm{pH}>$ IEP. The adsorption and zeta potential are consistent, since only the adsorbed HA is expected to affect zeta potential [13]. This trend was also existed when there were nanoparticles in the solution which was showed in Fig. S3.

The results in Fig. S3 indicated that the addition of HA solution could decrease the zeta potential of suspension at lower concentration $(1.5 \mathrm{mg} / \mathrm{L}$ and $2.5 \mathrm{mg} / \mathrm{L})$, but when the concentration of DOC exceeded $3.5 \mathrm{mg} / \mathrm{L}$, the zeta potential was almost the same. As can be seen, $\mathrm{HA}$ causes the water samples with $\mathrm{Al}_{2} \mathrm{O}_{3}$ to under charge reversal. At high concentration of DOC, the particles undergo charge reversal and therefore particle stability is largely controlled by repulsive electrostatic interactions between adsorbed HA layers.

In order to investigate the interaction between nanoparticles and HA molecules, we investigated the zeta potential of HA solution (DOC $2.5 \mathrm{mg} / \mathrm{L}), \mathrm{HA}$ (DOC $2.5 \mathrm{mg} / \mathrm{L})+\mathrm{TiO}_{2}(2.0 \mathrm{mg} / \mathrm{L})$ solution, $\mathrm{HA}(\mathrm{DOC} 2.5 \mathrm{mg} / \mathrm{L})+\mathrm{Al}_{2} \mathrm{O}_{3}(2.0 \mathrm{mg} / \mathrm{L})$ solution under different $\mathrm{pH}$. The results in Fig. S4 indicated that the nature of $\mathrm{TiO}_{2}$ particles was affected by $\mathrm{pH}$ [25-28]: the surface was positively charged in acid condition but negatively charged in basic condition. The positive charged $\mathrm{TiO}_{2}$ surface hydroxyls were mainly $\mathrm{TiOH}_{2}^{+}$and negative charged $\mathrm{TiO}_{2}$ surface hydroxyls were $\mathrm{TiO}^{-}$in acidic and basic solution respectively [29]. The HA molecules became more negatively charged as $\mathrm{pH}$ value increased due to ionization of carboxylic and phenolic groups of HA. The dissociation of carboxylic groups usually takes place at $\mathrm{pH}>4$ whereas the phenolic groups undergo
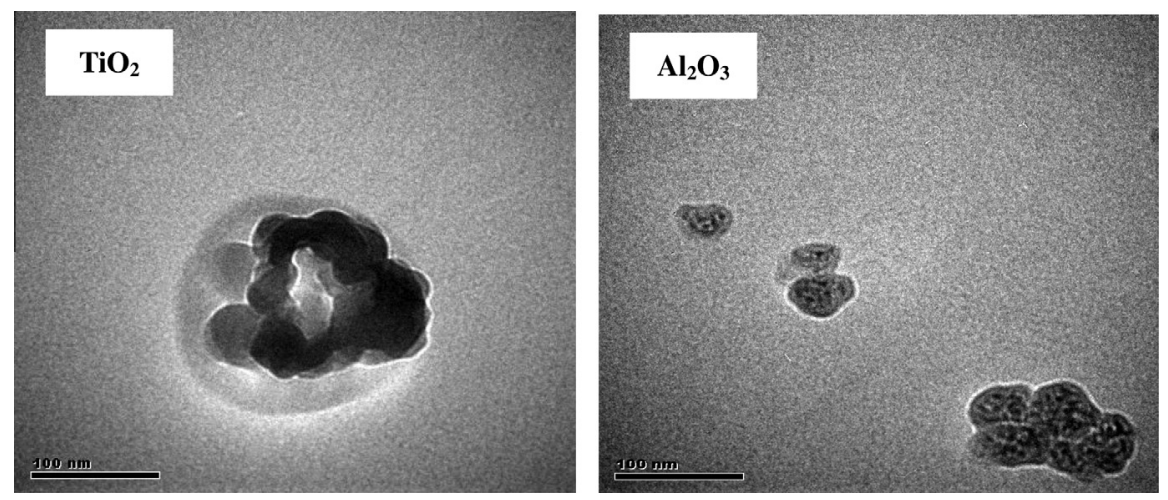

Fig. 1. TEM images of $\mathrm{TiO}_{2}$ and $\mathrm{Al}_{2} \mathrm{O}_{3}$ used in this study. 
Table 1

Characteristics of water samples used in this study.

\begin{tabular}{|c|c|c|c|c|c|c|c|}
\hline Concentration of nanoparticles $(\mathrm{mg} / \mathrm{L})$ & 0.0 & 0.2 & 0.4 & 0.8 & 1.2 & 1.6 & 2.0 \\
\hline $\begin{array}{l}\text { Kaolin suspension } \\
\text { Zeta potential }(\mathrm{mV})\end{array}$ & & & & & & & \\
\hline $\begin{array}{l}\mathrm{Al}_{2} \mathrm{O}_{3} \\
\mathrm{TiO}_{2}\end{array}$ & $\begin{array}{l}-30.1 \\
-30.1\end{array}$ & $\begin{array}{l}-20.1 \\
-33.2\end{array}$ & $\begin{array}{l}-10.2 \\
-38.7\end{array}$ & $\begin{array}{l}-8.1 \\
-42.3\end{array}$ & $\begin{array}{l}2.3 \\
-45.4\end{array}$ & $\begin{array}{l}10.2 \\
-45.8\end{array}$ & $\begin{array}{l}13.5 \\
-49.5\end{array}$ \\
\hline $\begin{array}{l}\text { Turbidity (NTU) } \\
\mathrm{Al}_{2} \mathrm{O}_{3} \\
\mathrm{TiO}_{2}\end{array}$ & $\begin{array}{l}29.7 \\
29.7\end{array}$ & $\begin{array}{l}30.2 \\
33.8\end{array}$ & $\begin{array}{l}31.3 \\
36.3\end{array}$ & $\begin{array}{l}32.5 \\
40.2\end{array}$ & $\begin{array}{l}33.8 \\
50.7\end{array}$ & $\begin{array}{l}34.8 \\
55.2\end{array}$ & $\begin{array}{l}35.1 \\
66.3\end{array}$ \\
\hline $\begin{array}{l}\text { Particle size }(\mu m) \\
\mathrm{Al}_{2} \mathrm{O}_{3} \\
\mathrm{TiO}_{2}\end{array}$ & $\begin{array}{l}2.208 \\
2.208\end{array}$ & $\begin{array}{l}2.214 \\
2.248\end{array}$ & $\begin{array}{l}2.387 \\
2.257\end{array}$ & $\begin{array}{l}2.458 \\
2.261\end{array}$ & $\begin{array}{l}2.517 \\
2.247\end{array}$ & $\begin{array}{l}2.67 \\
2.25\end{array}$ & $\begin{array}{l}2.845 \\
2.26\end{array}$ \\
\hline
\end{tabular}

dissociation at $\mathrm{pH}>8$. The zeta potential curve evidenced that the main factor that affected the adsorption extent was of electrostatic origin as agreed by many researchers. At $\mathrm{pH}<5$, negatively charged HA would adsorb on positively charged $\mathrm{TiO}_{2}$ particles due to the electrostatic attraction. At $\mathrm{pH}>5$, both negatively charged $\mathrm{HA}$ and $\mathrm{TiO}_{2}$ particles generated a strong electrostatic barrier which would inhibit the adsorption process. However HA adsorption did occur above PZC suggested that adsorption other than the electrostatic interaction between $\mathrm{HA}$ and $\mathrm{TiO}_{2}$ particles must exist. The similar trend was also existed in $\mathrm{HA}$ and $\mathrm{Al}_{2} \mathrm{O}_{3}$ system. Researchers [30] observed that the surface of nanozero-valent iron (NZVI) used for groundwater remediation can be modified via coating with organic stabilizers. NOM is likely to coat $\mathrm{TiO}_{2}$ nanoparticles discharged into the aquatic environment [31]. In addition, researchers [32,33] showed that anions increased the negative charge density adjacent to the mineral particle surface and could cause a shift in the position of the shear plane further away from the surface.

In order to investigate the effects of ionic strength, we adjusted the ionic strength to $0.5 \mathrm{mmol} / \mathrm{L}, \quad 1.0 \mathrm{mmol} / \mathrm{L}, \quad 3.0 \mathrm{mmol} / \mathrm{L}$, $5.0 \mathrm{mmol} / \mathrm{L}, 7.0 \mathrm{mmol} / \mathrm{L}, 10.0 \mathrm{mmol} / \mathrm{L}, 20.0 \mathrm{mmol} / \mathrm{L}$ by adding different concentration of $\mathrm{NaNO}_{3}$ and the alkalinity was also provided by $4.0 \mathrm{mmol} / \mathrm{L} \mathrm{NaHCO}_{3}$. Water samples were prepared by diluting from kaolin stock solution. The coagulation $\mathrm{pH}$ value was adjusted to 7.0 before the addition of coagulant. AS was used as coagulant.

\subsection{Chemicals and coagulants}

All reagents used were of analytical grade and de-ionized water was used in all solutions. The AS coagulant was prepared by dissolving a certain amount of $\mathrm{Al}_{2}\left(\mathrm{SO}_{4}\right)_{3} \cdot 18 \mathrm{H}_{2} \mathrm{O}$ to de-ionized water. $\mathrm{PACl}$ was diluted from commercial PACl. Initial alum speciation of coagulant was determined by the ferron method [34]. The results were summarized in Table 2 .

\subsection{Jar tests and removal efficiency for nanoparticles}

Coagulation experiments were conducted in $500 \mathrm{ml}$ beakers using conventional Jar-test apparatus at room temperature. Samples were mixed at $250 \mathrm{r} / \mathrm{min}$ for $30 \mathrm{~s}$, and they were mixed at $200 \mathrm{r} / \mathrm{min}$ for $90 \mathrm{~s}$ after coagulants addition to provide rapid mixing, and then the speed was reduced to $40 \mathrm{r} / \mathrm{min}$ for $10 \mathrm{~min}$

Table 2

Alum speciation of coagulant.

\begin{tabular}{llll}
\hline & $\mathrm{Al}_{\mathrm{a}}(\%)$ & $\mathrm{Al}_{\mathrm{b}}(\%)$ & $\mathrm{Al}_{\mathrm{c}}(\%)$ \\
\hline $\mathrm{AS}$ & 93.78 & 6.22 & 0 \\
$\mathrm{PACl}$ & 31.33 & 26.09 & 42.58 \\
\hline
\end{tabular}

to provide coagulation. After $30 \mathrm{~min}$ of settling, the supernatant from each jar test was withdraw from the beakers and analyzed for residual turbidity and the removal efficiency for nanoparticles.

Initially, coagulation experiments were performed to ascertain the optimum dosage for turbidity removal under different conditions. The initial $\mathrm{pH}$ of kaolin solution $(29.7 \mathrm{mg} / \mathrm{L})$ was adjusted at 7.0 by $0.1 \mathrm{~mol} / \mathrm{L} \mathrm{HCl}$ and $0.1 \mathrm{~mol} / \mathrm{L} \mathrm{NaOH}$ solutions. The residual turbidity and zeta potential for AS and PACl were comparatively investigated.

The kaolin particles used in this study were digested by microwave. The solutions were measured by an inductively coupled plasma mass spectrometer (ICP-MS, ICAP Q, Thermo Fischer). The different components are summarized in Table 3. The kaolin had $\mathrm{Al}$ and $\mathrm{Ti}$ elements. After the coagulation, the finished water was also digested. The removal efficiency for two nanoparticles can be measured through the ratio of $\mathrm{SiO}_{2} / \mathrm{Al}_{2} \mathrm{O}_{3}$ and $\mathrm{SiO}_{2} / \mathrm{TiO}_{2}$. The concentration of nanoparticles used in this study was $2.0 \mathrm{mg} / \mathrm{L}$ for two nanoparticles. AS was used as coagulant, and the $\mathrm{pH}$ was adjusted to $6.0,7.0$ or 8.5 .

\subsection{Floc formation, breakage and re-growth}

After 10 min of slow mixing period, the mixing speed was increased to $200 \mathrm{rpm}$ for $5 \mathrm{~min}$ for breakage, followed by another slow mixing at $40 \mathrm{rpm}$ for $10 \mathrm{~min}$ for flocs to reform. The dynamic floc sizes were measured using laser diffraction Mastersizer 2000. The suspension was monitored through optical unit of Mastersizer and back into the jar by a peristaltic pump. In order to investigate the effect of solution $\mathrm{pH}$ on floc breakage and re-growth, the $\mathrm{pH}$ values were adjusted to $6.0,7.0$ or 8.5 . In addition, a series of jar tests were conducted to investigate the effect of concentration of $\mathrm{TiO}_{2}$ or $\mathrm{Al}_{2} \mathrm{O}_{3}$ on floc strength and recovery ability.

\subsection{Floc strength and recovery factors}

Strength factor $\left(S_{f}\right)$ and recovery factor $\left(R_{f}\right)$ are well-established parameters for describing floc strength and recovery ability and can be calculated as follows [34]:

$S_{f}=\frac{d_{2}}{d_{1}}$
$R_{f}=\frac{d_{3}-d_{2}}{d_{1}-d_{2}}$

Table 3

Components of the kaolin particles used in this study.

\begin{tabular}{lllllll}
\hline Components & $\mathrm{SiO}_{2}$ & $\mathrm{Al}_{2} \mathrm{O}_{3}$ & $\mathrm{TiO}_{2}$ & $\mathrm{CaO}$ & $\mathrm{Fe}_{2} \mathrm{O}_{3}$ & $\mathrm{MgO}$ \\
\hline Content (\%) & 55.18 & 42.19 & 0.24 & 0.27 & 0.97 & 0.21 \\
\hline
\end{tabular}


The $d_{1}, d_{2}, d_{3}$ are the sizes of floc in the steady phase before breakage, after the breakage period and after the re-growth to another steady phase, respectively.

\subsection{Fractal dimension}

A brief description is given here of the widely used light scattering method for the determination of aggregate mass fractal dimension [24]. The technique involves measurement of light intensity I as a function of the scatter vector $Q$.

For independently scattering aggregates, the relationship among $I, Q$ and the fractal dimension $D_{f}$ can be represented by Eq. (3):

$I \propto Q^{D_{f}}$

The relationship shown in Eq. (3) indicates the determination of $D_{f}$, which can be given by the slope of $\log I$ versus $\log Q$ by fitting a straight line.
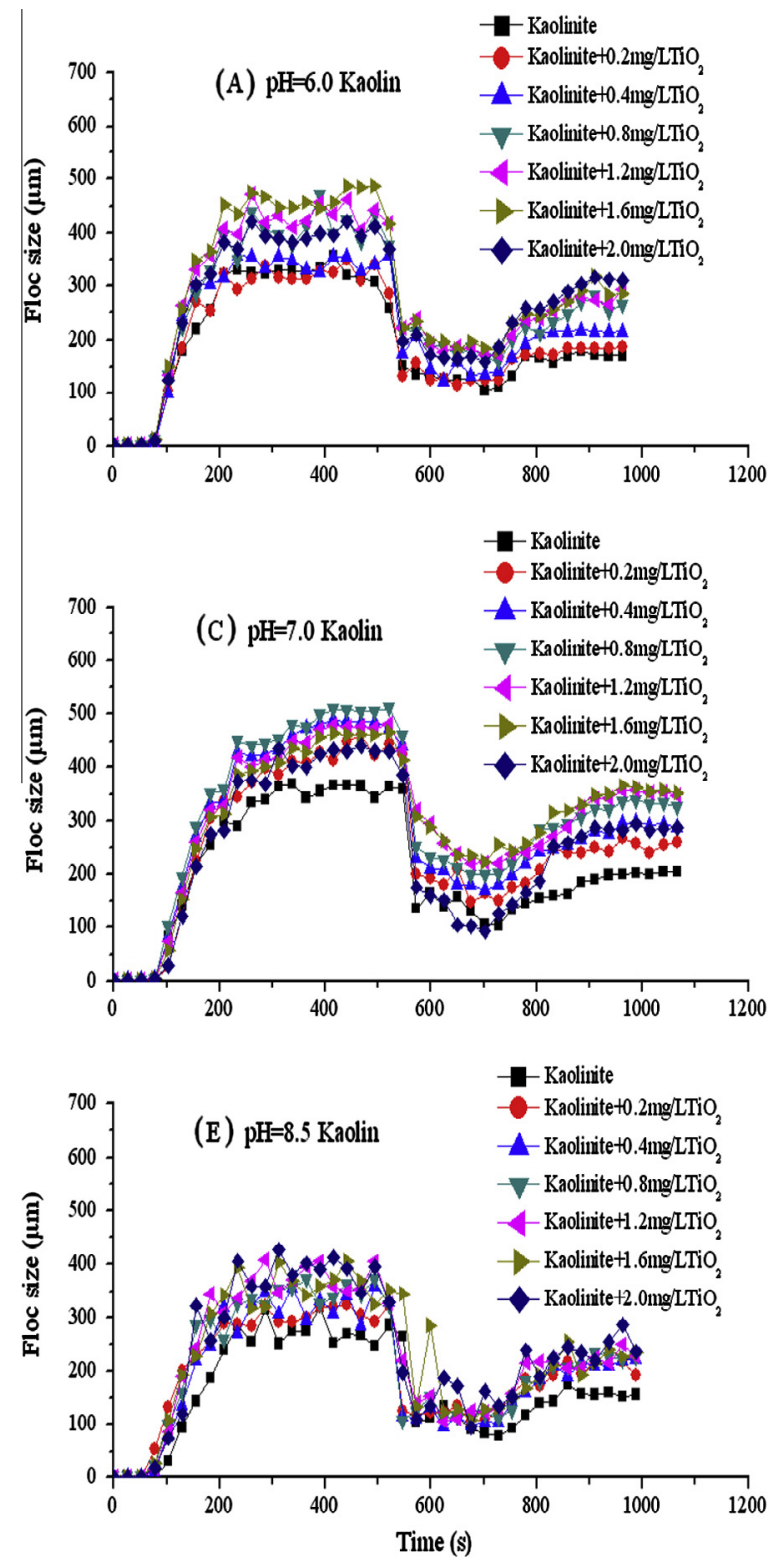

The floc growth rate was calculated by the slope of the rapid growth region, which was shown in Eq. (4):

Growth rate $=\frac{\Delta \text { size }}{\Delta \text { time }}$

\section{Results and discussion}

\subsection{Dosage optimum}

The residual turbidity and zeta potential for AS and PACl were comparatively investigated (Fig. S5). Results showed the variation of turbidity removal and zeta potential as a function of the coagulant dosage. It was found that when $\mathrm{Al}$ dosages ranged from 0.02 to $0.3 \mathrm{mmol} / \mathrm{L}$ calculated as $\mathrm{Al}$, the turbidity removal increased gradually with the increase of coagulant dosage before reaching the optimum dosage. The optimum dosage for turbidities was at $0.1 \mathrm{mmol} / \mathrm{L}$ for two coagulants. It can be seen that as the coagulants dosages increased, zeta potential was gradually
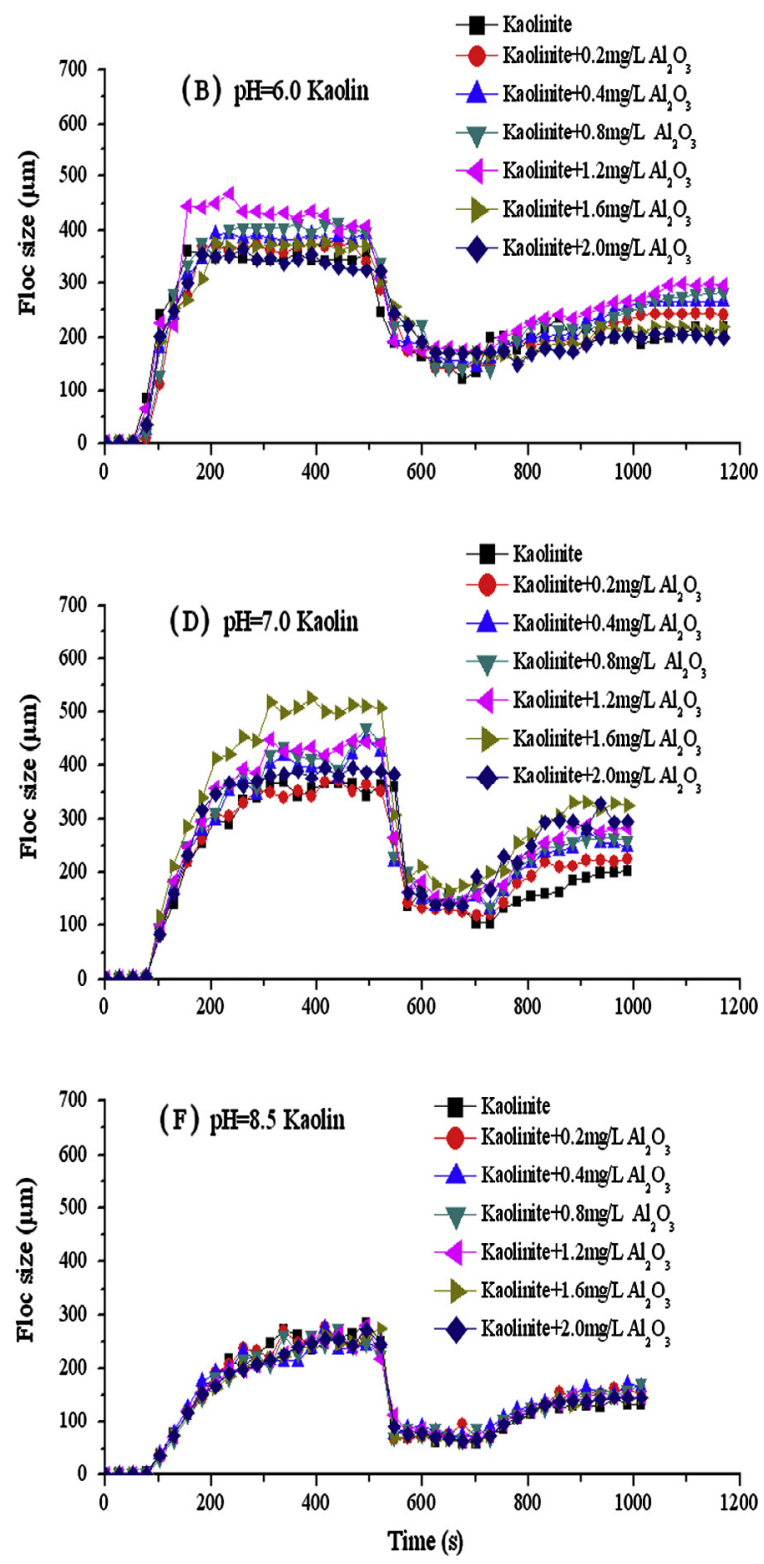

Fig. 2. Floc size in the coagulant process under different conditions (kaolin suspension at pH =6.0, 7.0 and 8.5). 
elevated. Floc zeta potential under optimum condition was $1.2 \mathrm{mV}$ for AS, and $4.5 \mathrm{mV}$ for PACl.

\subsection{Effects of nanoparticles on the coagulation process without HA}

In this part, the water sample was diluted from the stock kaolin solution. The concentration of kaolin was $29.7 \mathrm{mg} / \mathrm{L}$. The concentration of nanoparticles used in this study was from $0.0 \mathrm{mg} / \mathrm{L}$ to $2.0 \mathrm{mg} / \mathrm{L}$ for $\mathrm{TiO}_{2}$ and $\mathrm{Al}_{2} \mathrm{O}_{3}$ particles in order to investigate the nanoparticles on the characteristics of flocs. The results of floc size under pH $6.0,7.0$ or 8.5 were summarized in Fig. 2 The floc size $(\mu \mathrm{m})$ after growth period, floc growth rate $(\mu \mathrm{m} / \mathrm{min})$, strength factor, recovery factor and fractal dimension under $\mathrm{pH} 7.0$ were summarized in Fig. 3. The characteristics of flocs formed under other two $\mathrm{pH}$ values are summarized in Table S1.

According to the results in Fig. 2A, floc size increased first, and decreased when the concentration of nanoparticles was high. The $\mathrm{TiO}_{2}$ had little negative charges on the surface under $\mathrm{pH}$ 6.0, so the decrease of floc size happened at concentration of $2.0 \mathrm{mg} / \mathrm{L}$. When $\mathrm{Al}_{2} \mathrm{O}_{3}$ particles were added to the suspension, the decrease happened at concentration of $1.6 \mathrm{mg} / \mathrm{L}$ (zeta potential $8.3 \mathrm{mV}$, Fig. 2B). From Fig. $\mathrm{S} 1$, the $\mathrm{Al}_{2} \mathrm{O}_{3}$ particles had more positive charges on the surface under $\mathrm{pH}$ 6.0, so when the concentration of $\mathrm{Al}_{2} \mathrm{O}_{3}$ was high, suspension was charge reversal.

The results of strength factor and recovery factor in Table S1 showed that when the concentration of $\mathrm{TiO}_{2}$ was larger than $0.4 \mathrm{mg} / \mathrm{L}$, the strength factor decreased from $31.14 \%$ to $25.00 \%$ under $\mathrm{pH}$ 6.0. The concentration of $\mathrm{Al}_{2} \mathrm{O}_{3}$ had no significant effects on the strength factor under $\mathrm{pH}$ 6.0. In the experiment condition, the
$\mathrm{Al}_{2} \mathrm{O}_{3}$ particles had positive charges, so the adsorption of $\mathrm{Al}$ coagulant was not significant. The bridging effects of $\mathrm{Al}_{2} \mathrm{O}_{3}$ were caused only by $\mathrm{Al}_{2} \mathrm{O}_{3}$ particles. The bridging force between $\mathrm{Al}_{2} \mathrm{O}_{3}$ particles and kaolin particles was smaller than the Al-species coagulant, so the concentration of $\mathrm{Al}_{2} \mathrm{O}_{3}$ particles had no significant effects on the strength factor. Licsko [35] showed that the hydrolysis of metal ions occurred immediately after contacting with water. The in situ formed $\mathrm{Al}_{13}$ was adsorbed on the $\mathrm{TiO}_{2}$ particles (negative charges under $\mathrm{pH}$ 6.0), so the recovery force was formed by $\mathrm{TiO}_{2}$ and Alspecies coagulant adsorbed on the surface of $\mathrm{TiO}_{2}$ particles. The amount adsorbed on the surface of $\mathrm{TiO}_{2}$ increased with increasing the concentration of $\mathrm{TiO}_{2}$, so the recovery factor also increased. The results of recovery factor indicated that the addition of $\mathrm{TiO}_{2}$ particles could increase the recovery factor from $34.49 \%$ to $54.27 \%$. The recovery factor with addition of $\mathrm{Al}_{2} \mathrm{O}_{3}$ increased firstly from $34.49 \%$ to $53.68 \%$, but it decreased to $34.09 \%$ when the concentration of $\mathrm{Al}_{2} \mathrm{O}_{3}$ was $2.0 \mathrm{mg} / \mathrm{L}$. The zeta potential with $2.0 \mathrm{mg} / \mathrm{L}$ of $\mathrm{Al}_{2} \mathrm{O}_{3}$ particles was $+20.0 \mathrm{mv}$, and the recovery factor decreased due to the repulsion force between particles.

The decrease of floc size happened at $1.2 \mathrm{mg} / \mathrm{L}$ for $\mathrm{TiO}_{2}$ under

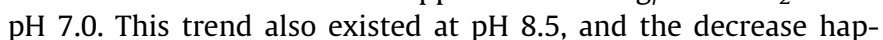
pened at $0.8 \mathrm{mg} / \mathrm{L}$. When the concentration of $\mathrm{Al}_{2} \mathrm{O}_{3}$ was larger than $1.6 \mathrm{mg} / \mathrm{L}$, the floc size decreased due to charge reversal (zeta potential $18.75 \mathrm{mv}$ ) which was shown in Fig. 2D.

The results of strength factor and recovery factor in Fig. 3 indicated that zeta potential of flocs had significant effects on the strength and recovery factor. The strength factor in existence of $\mathrm{TiO}_{2}$ increased from $28.79 \%$ to $48.69 \%$, and when the concentration of $\mathrm{TiO}_{2}$ was larger than $1.6 \mathrm{mg} / \mathrm{L}$, the strength factor decreased to
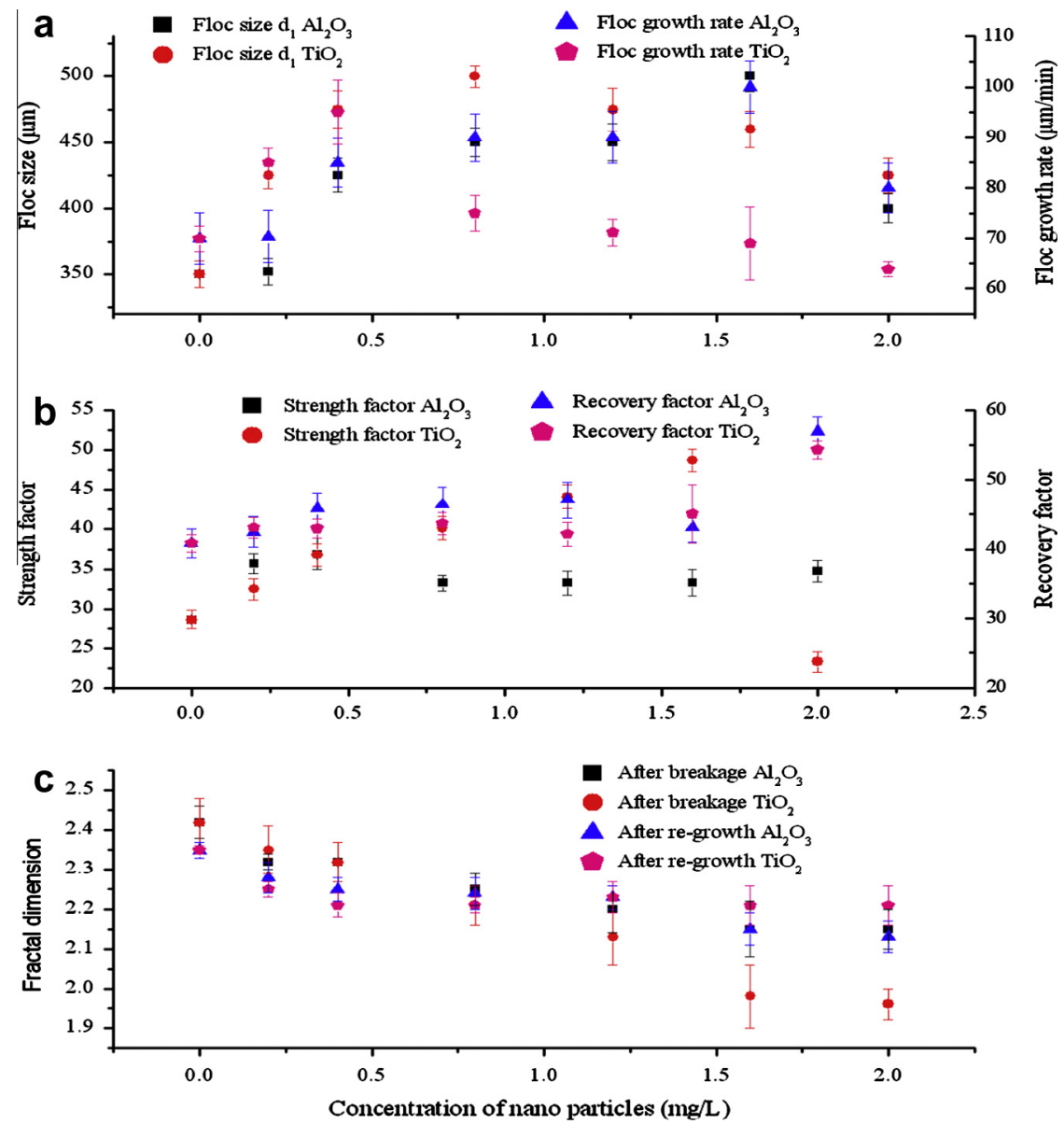

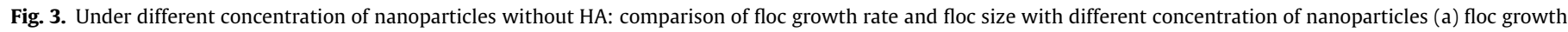
rate and floc size (b) strength factor and recovery factor and (c) fractal dimension. 
23.39\%. When the $\mathrm{pH}$ value was adjusted to 7.0 , the positive charges on the $\mathrm{Al}_{2} \mathrm{O}_{3}$ particles decreased, so some $\mathrm{Al}$ hydrolyzed species could be adsorbed on the $\mathrm{Al}_{2} \mathrm{O}_{3}$ particles. The bridging effect between $\mathrm{Al}_{2} \mathrm{O}_{3}$ particles and kaolin particles was not only by the $\mathrm{Al}_{2} \mathrm{O}_{3}$ particles. The adsorption of $\mathrm{Al}$ hydrolyzed species increased with increasing the concentration of $\mathrm{Al}_{2} \mathrm{O}_{3}$. The strength factor increased once there were $\mathrm{Al}_{2} \mathrm{O}_{3}$ particles in solution.

The floc sizes were the smallest in all three $\mathrm{pH}$ values (Fig. $2 \mathrm{E}$ and $\mathrm{F}$ ), and the concentration of $\mathrm{Al}_{2} \mathrm{O}_{3}$ had no significant effects on the floc size. Because the addition of AS $(0.1 \mathrm{mmol} / \mathrm{L}$ calculated as $\mathrm{Al}$ ) at $\mathrm{pH} 8.5$ made the solution negative in zeta potential, the floc size was smaller than other two $\mathrm{pH}$ values. The $\mathrm{pH}$ value was close to iso-electric point of $\mathrm{Al}_{2} \mathrm{O}_{3}$, and the bridging effects of nanoparticles decreased.

The results of strength factor and recovery factor at $\mathrm{pH} 8.5$ indicated that strength factor and recovery factor decreased when the concentration of $\mathrm{TiO}_{2}$ was $1.2 \mathrm{mg} / \mathrm{L}$. Because of zeta potential of water sample was close to $0 \mathrm{mv}$ with $2.0 \mathrm{mg} / \mathrm{L} \mathrm{Al}_{2} \mathrm{O}_{3}$ particles, the strength factor increased from $28.17 \%$ to $42.95 \%$. Previous results indicated that $\mathrm{pH}$ had a significant effect on further transformation of $\mathrm{PACl}$. In the acid region, $\mathrm{Al}_{\mathrm{a}}$ decreases rapidly as $\mathrm{pH}$ is raised, and reaches a minimum in the near neutral $\mathrm{pH}$ region. Upon increase of $\mathrm{pH}$ to the alkaline region, $\mathrm{Al}_{\mathrm{a}}$ species increase sharply again. In contrast, a rapid increase of the $\mathrm{Al}_{\mathrm{b}}$ species can be observed in the acidic $\mathrm{pH}$ region. The maximum of $\mathrm{Al}_{\mathrm{b}}$ occurs in the near neutral $\mathrm{pH}$ conditions. In the alkaline portion, a rapid decrease occurs as $\mathrm{pH}$ is raised [36].

The results of fractal dimension in Fig. $3 c$ indicated that the addition of nanoparticles decreased the fractal dimension. This was in agreement with previous study [37], and the larger flocs had smaller fractal dimension. When the concentration of $\mathrm{TiO}_{2}$ was larger than $0.8 \mathrm{mg} / \mathrm{L}$, the fractal dimension after re-growth was larger than fractal dimension after breakage. And the concentration for $\mathrm{Al}_{2} \mathrm{O}_{3}$ was $1.2 \mathrm{mg} / \mathrm{L}$. These results indicated that the nanoparticles existed in solution could bridge the kaolin particles together, and the bridging effects increased with increasing the concentration of nanoparticles.

The removal efficiencies for $\mathrm{Al}_{2} \mathrm{O}_{3}$ were $58.27 \%, 62.73 \%$ and $47.3 \%$ under $\mathrm{pH} 6.0,7.0$ and 8.5, respectively. The removal efficiencies for $\mathrm{TiO}_{2}$ were $38.12 \%, 52.25 \%$ and $27.19 \%$. The iso-electric points for $\mathrm{Al}_{2} \mathrm{O}_{3}$ and $\mathrm{TiO}_{2}$ were 8.5 and 4.8 respectively, and the $\mathrm{Al}_{2} \mathrm{O}_{3}$ particles would be adsorbed on kaolin particles because of different charges. The adsorption of $\mathrm{TiO}_{2}$ was not significant. The removal efficiency for nanoparticles may be affected by two mechanisms: one is the adsorption of nanoparticles on kaolin surface; the other is the coagulation process. When the $\mathrm{pH}$ was adjusted
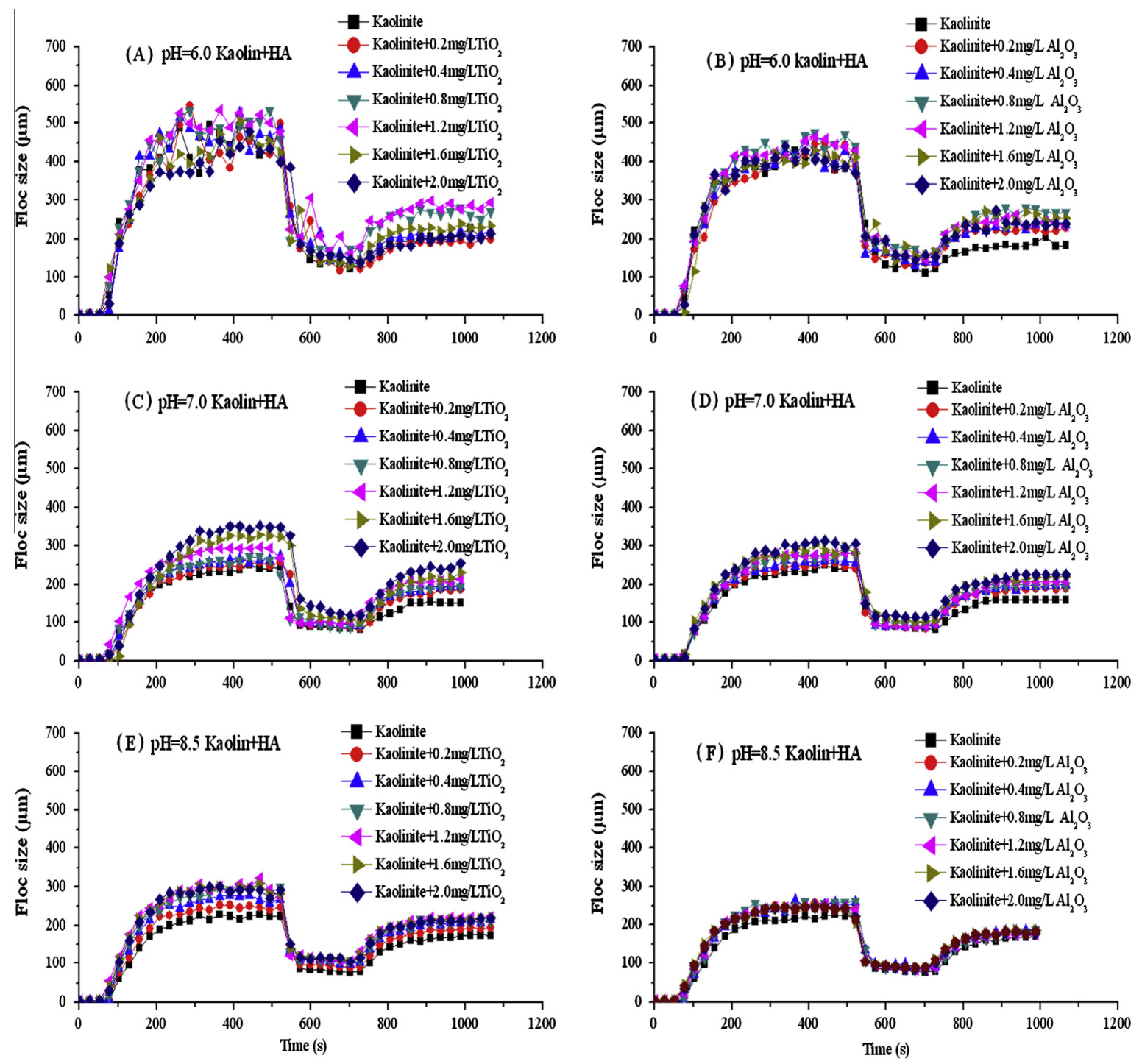

Fig. 4. Floc size in the coagulant process under different conditions (kaolin suspension $+\mathrm{HA}$ at $\mathrm{pH}=6.0,7.0$ and 8.5 ). 
to 8.5 , the charges on $\mathrm{Al}_{2} \mathrm{O}_{3}$ particles were almost $0 \mathrm{mv}$. So the adsorption process was hindered, and the removal efficiency also decreased. When the $\mathrm{pH}$ was adjusted to 6.0, the removal efficiency also decreased because of the Al hydrolysis was hindered.

The effects of the ionic strength (Fig. S6) indicated that it had significant effects on the coagulation process. Floc size after growth increased from $212 \mu \mathrm{m}$ to $350 \mu \mathrm{m}$ in kaolin system with increasing ionic strength from $0.5 \mathrm{mmol} / \mathrm{L}$ to $5.0 \mathrm{mmol} / \mathrm{L}$. An increase in the ionic strength leads to a corresponding higher growth rate for the flocs. However, increases in the ionic strength did not have a significant influence on the floc growth rate, when the ionic strength was larger than $5.0 \mathrm{mmol} / \mathrm{L}$ in kaolin system. The floc growth rate decreased because of charge reversal at larger ionic strength $(20.0 \mathrm{mmol} / \mathrm{L})$. The results of strength factor and recovery factor indicated that they increased with increasing ionic strength and zeta potential played a significant role. The strength factor and recovery factor increased with increasing the ionic strength, and decreased when the ionic strength was large. The addition of nanoparticles could significantly increase the recovery factor, and this increase was more significant when the ionic strength was larger than $5.0 \mathrm{mmol} / \mathrm{L}$. This may be caused by the adsorption of $\mathrm{Na}^{+}$on the surface of nanoparticles.

The zeta potential generally increased with the increase of ionic strength. The increase in ionic strength resulted in compression of the EDL and therefore a decrease in the EDL repulsive energy. Our results clearly indicated that the addition of ionic strength reduced the repulsion force among the particles, so they could aggregate and merge together to form larger flocs. Such a complex behavior is explained by the fact that the presence of salt is expected to influence two important parameters. The first one is related to the coagulation process at low salt concentration; to reduce the particle-particle repulsive force. The second one is related to the importance of the charge screening by increasing further the salt concentration. This effect is expected to increase the aggregation rate between the kaolin particles and nanoparticles.

\subsection{Effects of nanoparticles on the coagulation process with $H A$ (DOC $2.5 \mathrm{mg} / \mathrm{L}$ )}

HA was abundant in soil and groundwater, and played important roles in both adsorption and electron transfer processes [38]. The physicochemical characteristics of NOM fractions may strongly alter the stability of inorganic colloids. Numerous studies have shown the stability impact of humic acids upon their sorption on inorganic colloids, predominantly through repulsive interactions due to the net negative surface charge development of the inorganic colloids $[39,40]$. Our study demonstrated that the hydrophobic nature of the HA molecules strongly influenced the aggregation of NPs, possibly through their conformation behavior in a particular solution condition. HA was prior to be adsorbed on the nanoparticles surface and form complex with functional groups, which occupied the active surface sites and hindered the contacts of Al.
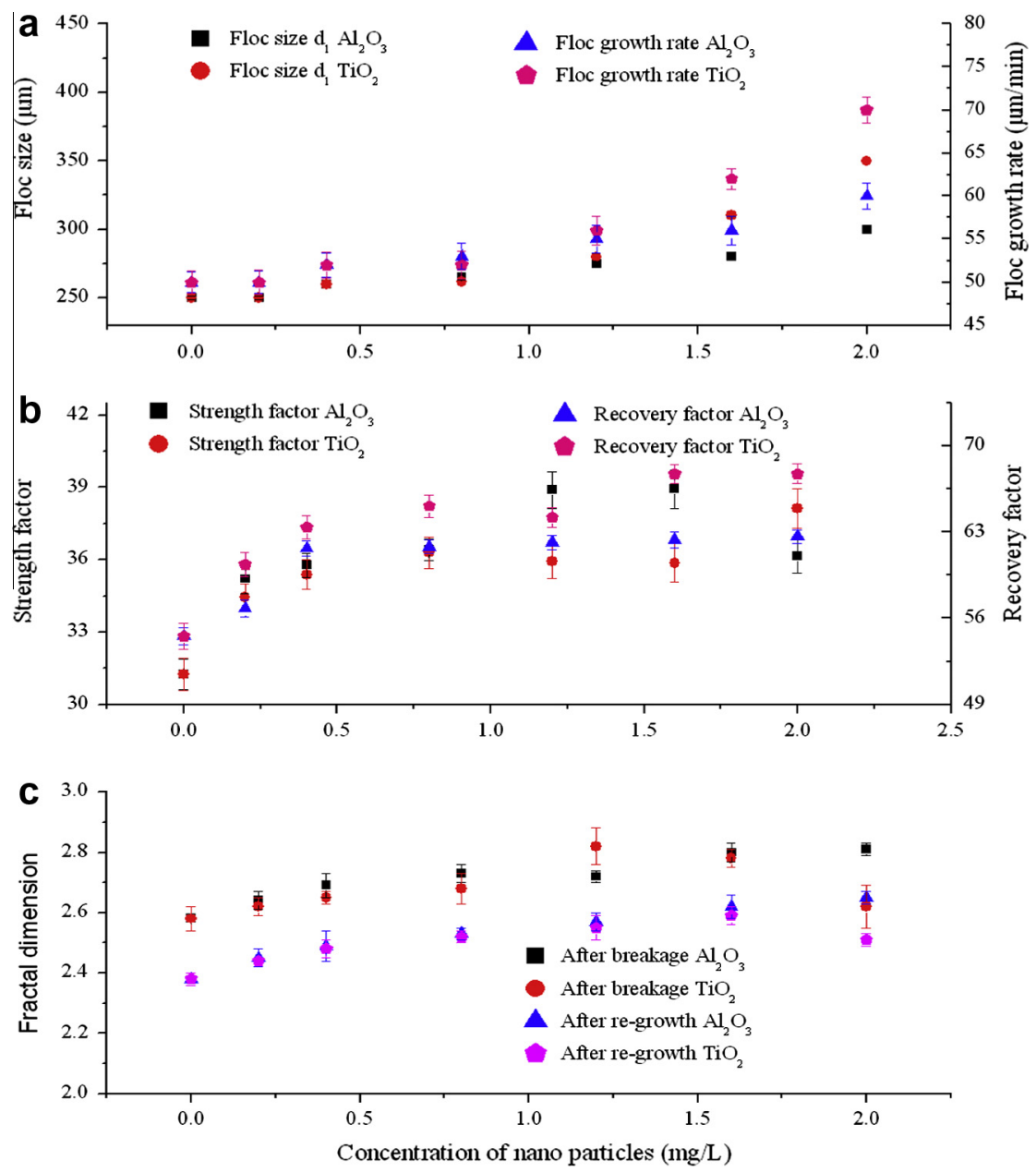

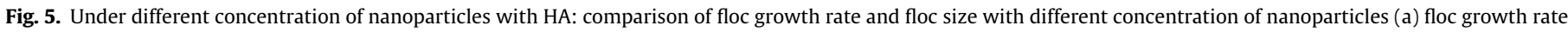
and floc size (b) strength factor and recovery factor and (c) fractal dimension. 
According to the results of Figs. 2A-B and 4A-B the addition of HA decreased floc size formed in this study. The results in Table S2 indicated that the strength factor increased from $27.09 \%$ to $32.33 \%$ with increasing the concentration of $\mathrm{TiO}_{2}$ from $0 \mathrm{mg} / \mathrm{L}$ to $1.2 \mathrm{mg} / \mathrm{L}$ under $\mathrm{pH}$ 6.0. The continuous increasing concentration of $\mathrm{TiO}_{2}$ had no significant effects on the strength factor. This trend was also observed when using $\mathrm{Al}_{2} \mathrm{O}_{3}$. The results of recovery factor indicated that the increasing concentration of nanoparticles could increase the recovery factor under $\mathrm{pH}$ 6.0. This may be caused by the bridging effects of nanoparticles with $\mathrm{HA}$ molecules. At acid condition, the $\mathrm{TiO}_{2}$ particles had less negative charges and $\mathrm{Al}_{2} \mathrm{O}_{3}$ particles had positive charges, so the bridging effects existed. The results of Fig. 4A-D indicated that the floc size decreased with increasing $\mathrm{pH}$ values. Because $\mathrm{Al}_{2} \mathrm{O}_{3}$ particles had positive charges on the surface, it could complex with functional groups of HA. Although the $\mathrm{TiO}_{2}$ particles had negative charges, the adsorption of $\mathrm{HA}$ on $\mathrm{TiO}_{2}$ particles also existed. So the nanoparticles can bridge the particles of HA molecules together. The recovery factor increased from $54.55 \%$ to $62.65 \%$ with increasing concentration of $\mathrm{Al}_{2} \mathrm{O}_{3}$ from $0.0 \mathrm{mg} / \mathrm{L}$ to $2.0 \mathrm{mg} / \mathrm{L}$, and it increased from $54.55 \%$ to $67.74 \%$ for $\mathrm{TiO}_{2}$ (Fig. 5b).

The results in Fig. $4 \mathrm{~F}$ indicated that the concentration of $\mathrm{Al}_{2} \mathrm{O}_{3}$ particles had no significant effects on the floc size formed in the coagulation process. This phenomenon was also observed in 3.2. According to the results in Table S2, the concentration of nanoparticles had no significant effects on the strength factors under $\mathrm{pH}$ 8.5. Recovery factor increased from $57.79 \%$ to $65.91 \%$ with increasing concentration of $\mathrm{TiO}_{2}$ from $0.0 \mathrm{mg} / \mathrm{L}$ to $2.0 \mathrm{mg} / \mathrm{L}$, and it increased from $57.79 \%$ to $62.7 \%$ for $\mathrm{Al}_{2} \mathrm{O}_{3}$.

The results of fractal dimension in Fig. $5 \mathrm{c}$ indicated that the addition of nanoparticles increased the fractal dimension first, and when the concentration of $\mathrm{TiO}_{2}$ was larger than $1.6 \mathrm{mg} / \mathrm{L}$, the fractal dimension after breakage decreased from 2.78 to 2.62 . The fractal dimension after breakage in the existence of $\mathrm{Al}_{2} \mathrm{O}_{3}$ increased from 2.58 to 2.81 with increasing the concentration of $\mathrm{Al}_{2} \mathrm{O}_{3}$ from $0.0 \mathrm{mg} / \mathrm{L}$ to $2.0 \mathrm{mg} / \mathrm{L}$.

\subsection{Effects of different coagulants on coagulation process under different concentration of $H A$}

The floc sizes under different concentration of DOC are summarized in Figs. 6 and 7. The concentrations of $\mathrm{TiO}_{2}$ and $\mathrm{Al}_{2} \mathrm{O}_{3}$ were $1.6 \mathrm{mg} / \mathrm{L}$ and $1.2 \mathrm{mg} / \mathrm{L}$.

According to the results in Fig. 6, the increasing of DOC decreased the floc size in all $\mathrm{pH}$ values. When the concentration

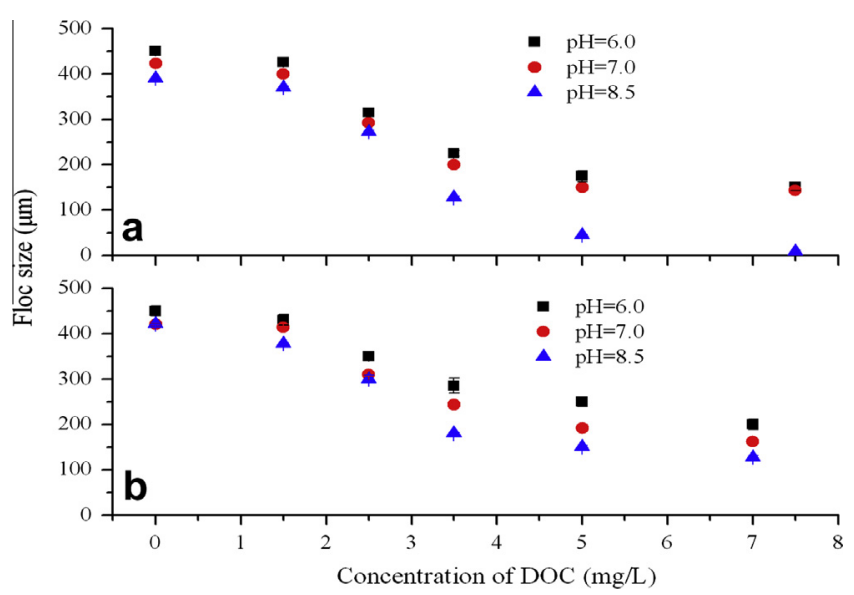

Fig. 6. Floc size after growth under different concentration of DOC using $\mathrm{AS}$ (a) $\mathrm{TiO}_{2}$ and (b) $\mathrm{Al}_{2} \mathrm{O}_{3}$.

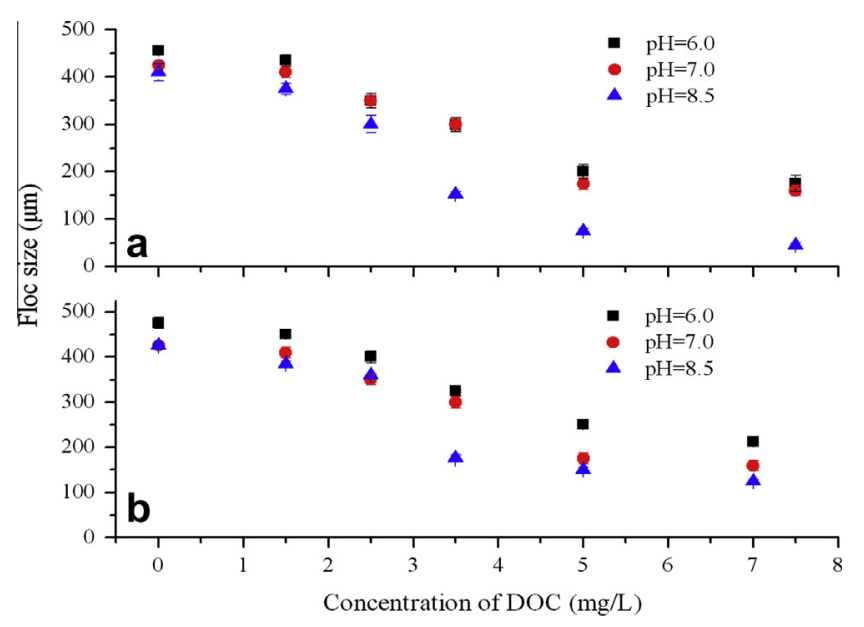

Fig. 7. Floc size after growth under different concentration of DOC using $\mathrm{PACl}$ (a) $\mathrm{TiO}_{2}$ and (b) $\mathrm{Al}_{2} \mathrm{O}_{3}$.

of DOC was larger than $5.0 \mathrm{mg} / \mathrm{L}$ under $\mathrm{pH} 8.5$, there was no floc formed in the coagulant process. $\mathrm{Al}_{2} \mathrm{O}_{3}$ particles had positive charges, and they were contributed to the growth of flocs under the same $\mathrm{pH}$ and coagulant dosage.

The results in Fig. 7 indicated that that $\mathrm{PACl}$ produced larger flocs. This may be caused by two mechanisms: one is the PACl has higher charge neutralization ability than AS; the other is the nanoparticles existed in the solution would adsorb $\mathrm{Al}_{13}$ in the $\mathrm{PACl}$ solution, and the electrostatic patch effect was larger than using AS.

The results of different concentration of DOC on the removal efficiencies for nanoparticles (Fig. S7) indicated that HA molecules played a significant role in the removal of nanoparticles. The removal efficiency for $\mathrm{TiO}_{2}$ decreased from $52.25 \%$ to $22.13 \%$ with increasing DOC from $0 \mathrm{mg} / \mathrm{L}$ to $7.5 \mathrm{mg} / \mathrm{L}$. The removal efficiency for $\mathrm{Al}_{2} \mathrm{O}_{3}$ decreased from $62.73 \%$ to $32.12 \%$. When there were $\mathrm{HA}$ molecules in the solution, the nanoparticles would adsorb HA molecules. The adsorption of nanoparticles on kaolin surface may be hindered. And there were still some HA molecules in the solution. The hydrolyzed $\mathrm{Al}$ species would react with particles and HA molecules, so the removal caused by coagulation process was also hindered.

\section{Conclusion}

Effects of different nanoparticles on the coagulation process were studied respectively. The floc size, flocs growth rate, strength factor, recovery factor and fractal dimension were comparatively investigated under different coagulation conditions. The removal efficiencies for two nanoparticles under different conditions were also investigated. The main conclusions from this work were listed as the following:

1. The zeta potential of flocs had significant effects on the strength and recovery factor in kaolin suspension. The strength factor with the presence of $\mathrm{TiO}_{2}$ increased from $28.79 \%$ to $48.69 \%$, and when the concentration of $\mathrm{TiO}_{2}$ was larger than $1.6 \mathrm{mg} / \mathrm{L}$, the strength factor decreased to $23.39 \%$ under $\mathrm{pH} 7.0$. The removal efficiencies for $\mathrm{Al}_{2} \mathrm{O}_{3}$ were $58.27 \%, 62.73 \%$ and $47.3 \%$ under $\mathrm{pH} 6.0,7.0$ or 8.5. The removal efficiencies for $\mathrm{TiO}_{2}$ were $38.12 \%, 52.25 \%$ and $27.19 \%$ respectively.

2. When the concentration of DOC was $2.5 \mathrm{mg} / \mathrm{L}$ under pH 7.0, the recovery factor increased from $54.55 \%$ to $62.65 \%$ with increasing concentration of $\mathrm{Al}_{2} \mathrm{O}_{3}$ from $0.0 \mathrm{mg} / \mathrm{L}$ to $2.0 \mathrm{mg} / \mathrm{L}$, and it increased from $54.55 \%$ to $67.74 \%$ for $\mathrm{TiO}_{2}$. The concentration of $\mathrm{Al}_{2} \mathrm{O}_{3}$ particles had no significant effects on the floc size formed in the coagulation process under $\mathrm{pH} 8.5$. 
3. The removal efficiency for $\mathrm{TiO}_{2}$ decreased from $52.25 \%$ to $22.13 \%$ with increasing concentration of DOC from $0 \mathrm{mg} / \mathrm{L}$ to $7.5 \mathrm{mg} / \mathrm{L}$. The removal efficiency for $\mathrm{Al}_{2} \mathrm{O}_{3}$ decreased from $62.73 \%$ to $32.12 \%$.

\section{Acknowledgements}

This research was supported by the National Basic Research Program (973 Program, Grant No. 2011CB933704) and the National Natural Science Foundation of China (Nos. 51378014, 51138008, 51025830, 51221892).

\section{Appendix A. Supplementary material}

Supplementary data associated with this article can be found, in the online version, at http://dx.doi.org/10.1016/j.seppur.2014.01. 010.

\section{References}

[1] M. Moore, Do nanoparticles present ecotoxicological risks for the health of the aquatic environment?, Environ Int. 32 (2006) 967-976.

[2] C.O. Robichaud, A.E. Uyar, M.R. Darby, L.G. Zucker, M.R. Wiesner, Estimates of upper bounds and trends in nano- $\mathrm{TiO}_{2}$ production as a basis for exposure assessment, Environ. Sci. Technol. 43 (2009) 4227-4233.

[3] M. Farvizi, T. Ebadzadeh, M.R. Vaeze, H.S. Kim, A. Simchi, Effect of nano $\mathrm{Al}_{2} \mathrm{O}_{3}$ addition on mechanical properties and wear behavior of NiTi intermetallic, Mater. Des. 51 (2013) 375-382.

[4] M. Ghosh, A. Chakraborty, A. Mukherjee, Cytotoxic, genotoxic and the hemolytic effect of titanium dioxide $\left(\mathrm{TiO}_{2}\right)$ nanoparticles on human erythrocyte and lymphocyte cell in vitro, J. Appl. Toxicol. 33 (2013) 10971110.

[5] B. Rehn, F. Seiler, S. Rehn, J. Bruch, M. Maier, Investigations on the inflammatory and genotoxic lung effects of two types of titanium dioxide: untreated and surface treated, Toxicol. Appl. Pharmacol. 189 (2003) 84-95.

[6] X.S. Liu, N. Huang, H. Li, Q. Jin, J. Ji, Surface and size effects on cell interaction of gold nanoparticles with both phagocytic and nonphagocytic cells, Langmuir 29 (2013) 9138-9148.

[7] D.H. Lin, J. Ji, Z.F. Long, K. Yang, F.C. Wu, The influence of dissolved and surfacebound humic acid on the toxicity of $\mathrm{TiO}_{2}$ nanoparticles to Chlorella sp, Water Res. 46 (2012) 4477-4487.

[8] J.Q. Jiang, Development of coagulation theory and pre-polymerized coagulants for water treatment, Sep. Purif. Rev. 30 (2001) 127-141.

[9] J. Ma, G.B. Li, Z.L. Chen, G.R. Xu, G.Q. Cai, Enhanced coagulation of surface waters with high organic content by permanganate preoxidation, Water Sci. Technol. 1 (2001) 51-62.

[10] S.H. Chuang, T.C. Chang, C.F. Ouyang, J.M. Leu, Colloidal silica removal in coagulation processes for wastewater reuse in a high-tech industrial park, Water Sci. Technol. 55 (2007) 187-195.

[11] R.S. Zhong, X.H. Zhang, F. Xiao, X.Y. Li, Effects of humic acid on recoverability and fractal structure of alum-kaolin flocs, J. Environ. Sci. 23 (2011) 731-737.

[12] R.J. Gibbs, Effect of natural organic coatings on the coagulation of particles, Environ. Sci. Technol. 17 (1983) 237-240.

[13] R. Kretzschmar, H. Sticher, D. Hesterberg, Effects of adsorbed humic acid on surface charge and flocculation of kaolinite, Soil Sci. Soc. Am. J. 61 (1997) $101-$ 108.

[14] M. Tirado-Miranda, A. Schmitt, J. Callejas-Fernández, A. Fernandez-Barbero, The aggregation behaviour of protein-coated particles: a light scattering study, Eur. Biophys. J. 32 (2003) 128-136.
[15] W.Y. Xu, B.Y. Gao, Q.Y. Yue, Q. Wang, Effect of preformed and non-preformed $\mathrm{Al}_{13}$ species on evolution of floc size, strength and fractal nature of humic acid flocs in coagulation process, Sep. Purif. Technol. 78 (2011) 83-90.

[16] J. Duan, J. Gregory, Coagulation by hydrolysing metal salts, Adv. Colloid Interface Sci. 100-102 (2003) 475-502.

[17] Y.Y. Yan, J.L. Burns, G.J. Jameson, S. Biggs, The structure and strength of depletion force induced particle aggregates, Chem. Eng. J. 80 (2000) 23-30.

[18] C. Selomulya, R. Amal, G. Bushell, T.D. Waite, Evidence of shear rate dependence on restructuring and breakup of latex aggregates, J. Colloid Interface Sci. 236 (2001) 67-77.

[19] W.Z. Yu, J. Gregory, Y.L. Yang, M. Sun, T. Liu, G.B. Li, Effect of coagulation and applied breakage shear on the regrowth of kaolin flocs, Environ. Eng. Sci. 27 (2010) 483-492.

[20] W.Z. Yu, G.B. Li, Y.P. Xu, X. Yang, Breakage and re-growth of flocs formed by alum and PACl, Powder Technol. 189 (2009) 439-443.

[21] C.P. Johnson, X.Y. Li, B.E. Logan, Settling velocities of fractal aggregates, Environ. Sci. Technol. 30 (1996) 1911-1918.

[22] X.Y. Li, B.E. Logan, Collision frequencies between fractal aggregates and small particles in a turbulently sheared fluid, Environ. Sci. Technol. 31 (1997) 12371242.

[23] M.A. Yukselen, J. Gregory, Breakage and re-formation of alum flocs, Environ. Eng. Sci. 19 (2002) 229-236.

[24] J.C. Wei, B.Y. Gao, Q.Y. Yue, Y. Wang, W.W. Li, X.B. Zhu, Comparison of coagulation behavior and floc structure characteristic of different polyferriccationic polymer dual-coagulants in humic acid solution, Water Res. 43 (2009) $724-732$.

[25] R.B. Bai, X. Zhang, Polypyrrole-coated granules for humic acid removal, J. Colloid Interface Sci. 243 (2001) 52-60.

[26] F.L. Palmer, B.R. Eggins, H.M. Coleman, The effect of operational parameters on the photocatalytic degradation of humic acid, J. Photochem. Photobiol., A 148 (2002) 137-143.

[27] J. Chorover, M.K. Amistadi, Reaction of forest floor organic matter at goethite, birnessite and smectite surfaces, Geochim. Cosmochim. Acta 65 (2001) 95109.

[28] K.K. Au, A.C. Penisson, S. Yang, C.R. O’Melia, Natural organic matter at oxide/ water interfaces: complexation and conformation, Geochim. Cosmochim. Acta 63 (1999) 2903-2917.

[29] C. Uyguner, M. Bekbolet, Evaluation of humic acid, chromium (VI) and $\mathrm{TiO}_{2}$ ternary system in relation to adsorptive interactions, Appl. Catal., B 49 (2004) 267-275.

[30] H.R. Dong, M.C. Irene, Influcence of humic acid on the colloid stability of surface modified nanozero valent iron, Water Res. 47 (2013) 419-427.

[31] D.H. Lin, J. Ji, Z.F. Long, K. Yang, F.C. Wu, The influence of dissolved and surfacebound humic acid on the toxicity of $\mathrm{TiO}_{2}$ nanoparticles to Chlorella sp, Water Res. 46 (2012) 4477-4487.

[32] D.D. Sun, P.F. Lee, $\mathrm{TiO}_{2}$ microsphere for the removal of humic acid from water: complex surface adsorption mechanisms, Sep. Purif. Technol. 91 (2012) 30-37.

[33] S. Ghosh, H. Mashayekhi, B. Pan, P. Bhowmik, B. Xing, Colloidal behavior of aluminum oxide nanoparticles as affected by $\mathrm{pH}$ and natural organic matter, Langmuir 24 (2008) 12385-12391.

[34] W.Y. Xu, B.Y. Gao, Y. Wang, Z.L. Yang, X.W. Bo, Role of $\mathrm{Al}_{13}$ species in removal of natural organic matter from low specific UV absorbance surface water and the aggregates characterization, Chem. Eng. J. 171 (2011) 926-934.

[35] I. Licsko, On the types of bond developing between the aluminium and iron (III) hydroxides and organic substances, Water Sci. Technol. 27 (1993) 249252.

[36] D.S. Wang, W. Sun, Y. Xu, H.X. Tang, J. Gregory, Speciation stability of inorganic polymer flocculant-PACl, Colloids Surf., A 243 (2004) 1-10.

[37] S. Wang, C. Liu, Q.L. Li, Impact of polymer flocculants on coagulationmicrofiltration of surface water, Water Res. 47 (2013) 4538-4546.

[38] M.R. Das, S. Mahiuddin, Kinetics and adsorption behaviour of benzoate andphthalate at the alpha alumina water interface: influence of functionality, Colloids Surf. 264 (2005) 90-100.

[39] E. Tipping, D.C. Higgins, The effect of adsorbed humic substances on the colloid stability of haematite particles, Colloids Surf. 5 (1982) 85-92.

[40] K. Wilkinson, J.C. Negre, J. Buffle, Coagulation of colloidal material in surface waters: the role of natural organic matter, J. Contam. Hydrol. 26 (1997) 229243. 